\title{
Strong Acid Effects for Characterization Clay from District Tanah Miring, Merauke Regency.
}

\author{
John Yoro Parlindungan*, and Abraham Laurens Rettob \\ Department of Chemical Education, Teacher Training and Education Faculty, Universitas Musamus, Merauke 99600, Indonesia
}

\begin{abstract}
The abundance of clay in the Merauke district has not been utilized optimally. This is due to a lack of research and information about these clays. Clay is one of the natural minerals from the silica group whose particle size is less than two micrometers and has many uses, including basic materials for the manufacture of ceramics, paper-making materials, adsorbents, assisting drilling, and bleaching in CPO. In this study, characterization has been carried out including functional group characterization using an FTIR spectrophotometer, crystallinity using XRD, and morphological analysis by SEM. The results obtained that the mineral content of the clay from the sloping soil district was proposed to contain Illite and Quartz minerals with the main peaks of the diffractogram appearing at an angle of $2 \theta$ about $21^{\circ} ; 26^{\circ} ; 36^{\circ}$; and $42^{\circ}$; at angles d $(\AA) 3.34$ and d $(\AA) 4.25$. XRD results were also tested using search-match analysis, and the sample intensity was obtained containing quartz minerals ( $98 \%)$. In the development of this material, it is necessary to obtain XRD data to determine the exact components of clay.
\end{abstract}

Keywords: Clay, Characterization, Quartz, Illite, Papua

\section{Introduction}

Indonesia has abundant natural potential as a source of oxide materials, for example, oxide material is contained in mining minerals, and the ingredients, such as (1) quartz sand with the dominant elemental content of quartz oxide $\left(\mathrm{SiO}_{2}\right)$, is widely used as raw material for ceramics, glass, glass. , cement, plates, other chemical industries, with a purity of up to $95-97 \%$; (2) clay is a type of clay rock predominantly composed of kaolinite minerals, as a source of alumina $\left(\mathrm{Al}_{2} \mathrm{O}_{3}\right)$ with distinctive physical properties, high degree of plasticity, widely used for the ceramic industry, up to $40 \%$ purity; (3) limestone, the most dominant oxide content is calcite $\left(\mathrm{CaCO}_{3}\right)$, which is carbonate sediment when given hydrochloric acid $(\mathrm{HCl})$ to release $\mathrm{CO}_{2}$ gas; widely used for portland cement, steel refining, paper industry, building materials, paint, and so on[1].

Merauke has soil types suitable for growing food, especially rice, namely the Vertic Endoaquept, Aeric Endoaquept, Typic Endoaquept, and Typic Plinthaquult. The four types of soil are generally clays[2].

Clay is a natural mineral from the silica group whose particle size is less than two micrometers and has a layer that contains a negative charge. Prihatin in Darwanta (2019) also categorizes clay in the solid group with the size below one micron and one type of clay with good adsorption ability [3].

\footnotetext{
*Corresponding author :parlindungan_fkip@unmus.ac.id
}

The composition of most clay soils consists of tetrahedral silica and aluminium octahedral. Tetrahedral silica is a combination of tetrahedral silica units consisting of silica atoms surrounded at the corners by four oxygen atoms. Aluminium octahedral is a combination of units consisting of one alumina atom surrounded by hydroxyl atoms on six sides. Silica and aluminium can be partially replaced by other elements in the unity, this condition is known as an isomorphic substance. The combination of the unified arrangement in the form of the plate arrangement is formed by the combination of the pile of the basic arrangement of different shapes [4].

Clay currently has many uses, including the basic material for making ceramics, ingredient paper making [5], adsorbent [6], assisting drilling, and bleaching in $\mathrm{CPO}[3]$. Currently in Merauke Regency, according to very limited observations, it is generally only used as a raw material for making bricks. This can be influenced by information about its usefulness due to the lack of research on the characteristics of clay originating from Merauke. By knowing the chemical characteristics of clay, it can be used for more uses and to improve the community's economy.

\section{Experiment}

This research is quantitative with the search and match method. The tools used in this study were mortal, pestle, 
a set of glassware for experiments, 200 mesh sieve, XRD Bruker D2 from Phaser, and SEM-EDX from Phenom Desktop ProXL. Meanwhile, the material is clorid acid $3 \mathrm{M}$ and clay from Tanah Miring, Merauke Regency.

\subsection{Sample Preparation}

The samples taken were immediately taken to the laboratory to be dried by aerating. After drying, the samples were crushed using a mortar and pestle and then filtered using a 200 mesh sieve. Furthermore, the sample was activated with clorid acid accompanied by heating and then analysed using SEM and XRD.

\section{Result and Discussion}

In this study, samples were taken from Tanah Miring to be precise in the village of Hidup Baru, Merauke Regency. The use of clay in this village is still limited to making bricks and several household tools such as pots and some utensils. Also, the availability of clay and purity is considered. From the observations, the colour of the clay in several places in the Tanah Miring District was different from one another. This is due to the composition of the elements that exist in the area [7].

The sample was yellow and still contained a lot of water when it was collected. So that before characterizing the clay must be dried first by aerating it. The use of the oven in drying tends to damage the structure of the clay which affects the SEM and XRD measurements [8].

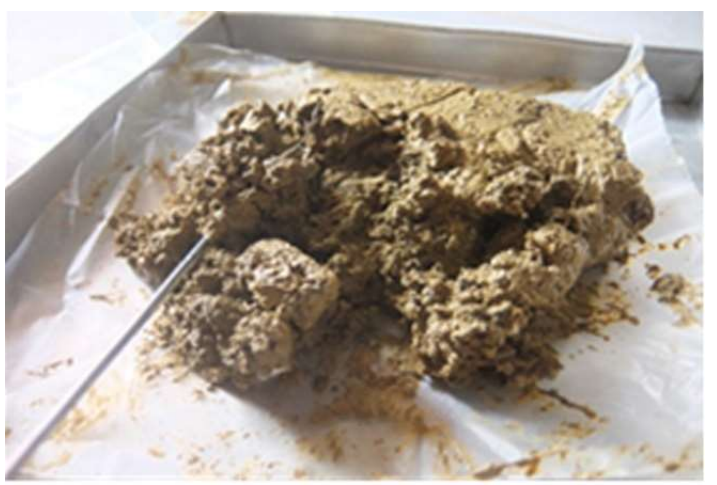

Fig. 1. Sample Before Preparation

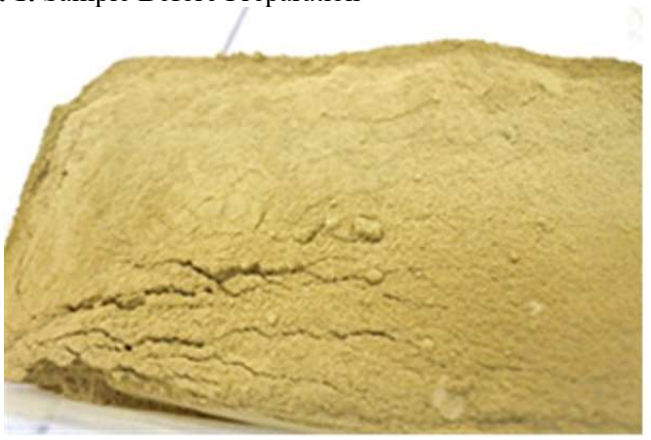

Fig. 2. Sample After Preparation

\subsection{SEM Analysis Result}

The analysis using SEM was carried out with a magnification of 5000 times and 15000 times as shown in the figure below.

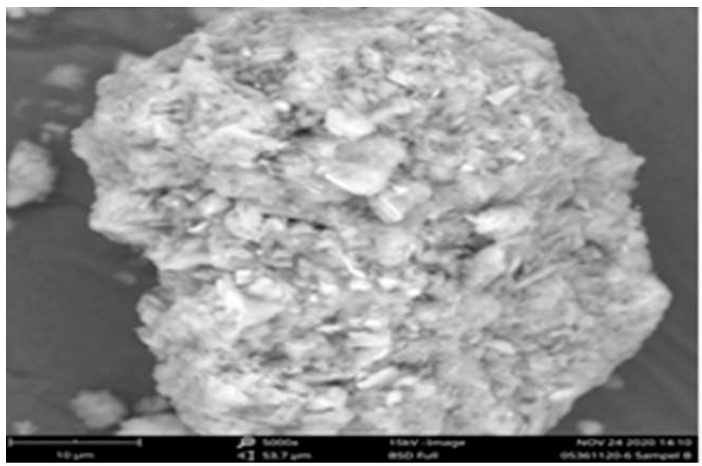

Fig. 3. SEM results display with 5000 times zoom.

Figure 3, show the appearance of clay-like grains with a shape like a sheet that is bending and dragging. This may refer that the clay consists of illite minerals with several features such as the presence of parts covered in rock flakes as bound minerals [6,7]. Besides, it can be seen that clay has a fairly large surface area with quite a lot of open pores.

At the magnification of 15000 times, the pores on the clay surface are visible. The analysis using SEM also shows that clay activation removes impurities such as $\mathrm{Ca}^{2+}, \mathrm{K}^{+}$, and $\mathrm{Na}^{+}$ions that are on the surface due to the addition of hydrochloric acid [9]. Apart from the surface area and the presence of pores, SEM can also show a tendency for the minerals that make up the clay. In Figure 2 it can be seen that the bending sheet is a characteristic of the mineral illite. Besides being dominated by illite, there are also kaolinite grade minerals which are shaped like tubes, and quartz which is shaped like a hard rock solid [7-9].

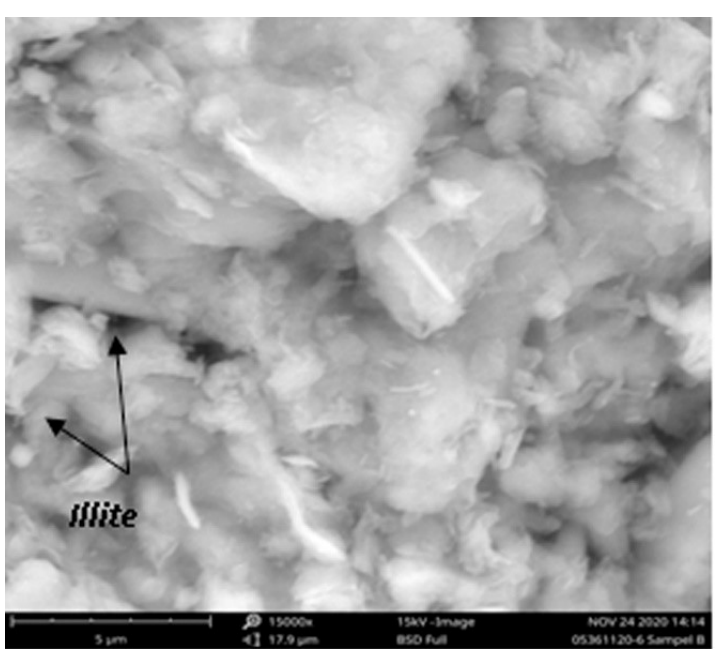

Fig. 4. Display of SEM results with 15000 times zoom.

\subsection{XRD Analysis Result}

The next characterization was to study the types of minerals contained in the clay using the XRD 
instrument. Results of the analysis. From the results of the diffractogram, it can be seen that the crystal regularity in the clay is very good seen from the XRD results which tend to be neat and sharp $[2,3]$.

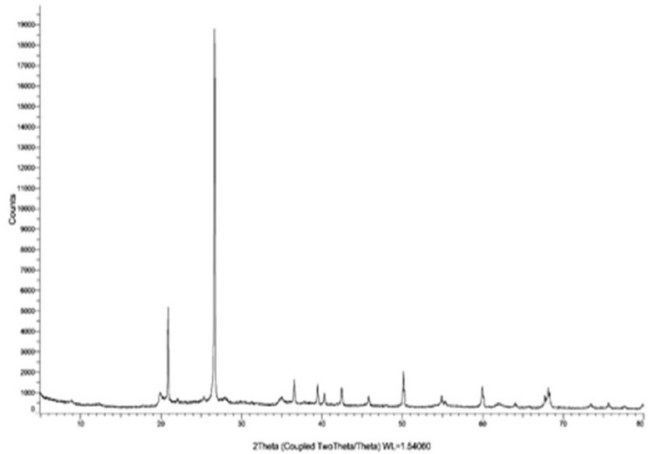

Fig. 5. Clay Sample Difragtogram

The diagram shows that the minerals in the clay from the sloping soil district can be proposed as predominantly containing Quartz and Illite. This can be seen from the main peaks of the diffractogram appearing at an angle of $2 \theta$ around $21^{\circ} ; 26^{\circ} ; 36^{\circ}$; and $42^{\circ}$; at angles $\mathrm{d}(\AA) 3.34$ and $\mathrm{d}(\AA)$ 4.25. XRD results were also tested using the search-match application. This application is application that helps analyze XRD results [10]. In this research, a trial version provided by the developer is used. The results obtained from the sample contain quartz minerals $(\sim 98 \%)$.

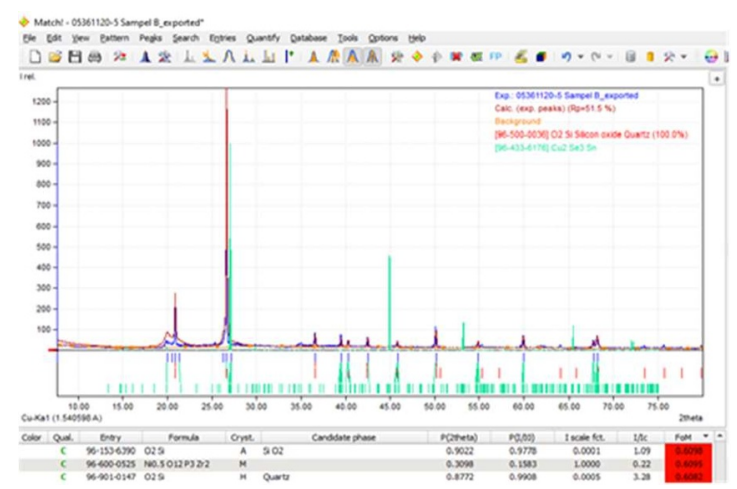

Fig. 6.The results of the analysis using Match

\section{Conclusion}

Research has been carried out to characterize the clay from Tanah Miring District, Merauke Regency uses SEM and XRD analysis. The results received were that the clay contained the minerals Illite and Quartz.

Thanks for LPPM Universitas Musamus that give me support for the author to do this research from DIPA UNMUS until this journal publish.

\section{References}

1. M. Munasir, T. Triwikantoro, M. Zainuri, and D. Darminto, J. Penelit. Fis. Dan Apl. 2, 20 (2012)
2. M. Al-Jabri and C. Tafakresnanto, in Kebijak. Dan Inf. Sumberd. Lahan (Balitbang Sumberdaya Lahan Pertanian, Departemen Pertanian Republik Indonesia, Bogor, (2008), pp. 281-299

3. Darwanta, Suwito, and H. Fatimah, Avogadro 3, 35 (2019)

4. M. Muslim, Karakterisasi Sifat Fisika Kimia Lempung Dari Daerah Kecamatan Watu Limo Dan Durenan Kabupaten Trenggalek, UIN Maulana Malik Ibrahim Malang, 2014

5. M. Elma, I. Syauqiah, N. Aldina, and H. Kesumadewi, Teknoin 22, 437 (2017)

6. J. Y. Parlindungan, J. J. Pongkendek, S. Wairara, and N. Abdullah, IOP Conf. Ser. Earth Environ. Sci. 343, 1 (2019)

7. N. S. Siddaiah and K. Kumar, Mem. Geol. Soc. India 72, 145 (2008)

8. H. Zhao, J. Liu, J. Guo, C. Zhao, and B. Gong, J. Mater. Civ. Eng. 27, 04014108 (2015)

9. E. D. Yanti, P. Iqbal, I. Pratiwi, and J. Jakah, J. Teknol. Miner. Dan Batubara 14, 93 (2018)

10. H. Senoussi, H. Osmani, C. Courtois, and M. E. H. Bourahli, Bol. La Soc. Esp. Ceram. y Vidr. 55, 121 (2016) 